\title{
The Charisma of Shangri-la
}

\author{
David A. Palmer
}

\author{
Review of The Spread of Tibetan Buddhism in China. Charisma, Money, Enlightenment \\ by Dan Smyer Yü. Abingdon, Oxon: Routledge, 2012. \\ PRE-PUBLICATION VERSION \\ Published in Current Anthropology 55:1, Feb. 2014.
}

Tibet looms large in the contemporary global spiritual landscape, as well as in Chinese state narratives of liberating the people from the bondage of serfdom and economic backwardness, and in Western perceptions of human rights abuses and religious repression by the socialist state. These images have in common the imagination of Tibet as a pristine landscape upon which are projected spiritual yearnings, political narratives or ideological struggles. Its inhabitants, culture and religion are portrayed as objects of destruction or resistance, in any case largely passive, within dramas whose scripts are written and consumed on the outside. Unbeknownst to most observers, however, has been the increasing popularity of Tibetan Buddhism among the Han Chinese. The Spread of Tibetan Buddhism in China by Dan Smyer Yü is the first account of this phenomenon, based on fieldwork conducted in the mountains and grasslands of Eastern Tibet as well as in Han cities and in Chinese cyberspace.

The ethnographic starting-point of the study is a Buddhist academy established in 1980 in Sertar County of the Ganzi Tibetan Autonomous Prefecture, in Western Sichuan. Founded by the charismatic monk Khenpo Jigme Phuntsok (d. 2004), the academy has become one of the largest Buddhist centres of learning in the world, attracting over 12,000 resident monks, nuns and lay practitioners, including several thousand Han as well as a number of Westerners. The academy has become the centre of a network reaching to China's metropolitan centres and engaging with the Chinese artistic and intellectual worlds, and has a significant presence in cyberspace through its influential websites on Buddhism.

Yü begins by exploring how lineages of reincarnate lamas or tulkus such as Khenpo Jigme Phuntsok, derive "territorial charisma" from their embedding in a specific landscape. In contrast to the vertical, Eliadian axis mundi of some of the most sacred Tibetan mountains, most Tibetans live within a horizontal, "inter-sentient" sacrality in which common people, souls, spirits, and the forms of the land are all animated, in constant inter-dwelling and reciprocal relations, with worldly concerns at the fore. In this inter-sentient modality, "mindscape" and "landscape" shape each other and become one. Mountains are the abodes of human souls, which "spiritize the landscapes in which they live". Through ritual acts, human communities engage in reciprocal give-and-take with the powers that surround them. All the parties, human and non-human, seek protection, power and prosperity. At this level, there is no fixed hierarchy but a constant negotiation between humans, spirits and animated landscape features. However, all are subordinate to the transcendental power of the Buddha Dharma; all are sentient beings subject to desires and rebirth. Tibetan landscapes typically embed local spirits which have been converted to Buddhism by great tulkus, domesticating them and turning them into lowerlevel Buddhist guardian spirits. As embodiments of the Dharma, tulkus thus become 
centres of territorial charisma, drawing localized powers around their own person and bringing them under the authority of the universal Dharma.

The spiritualization of the Tibetan landscape is manifest in the way Tibetans cultivate and modify the landscape, adding to its aesthetic sublimity through their human constructions and markings. The contrast, for pilgrims approaching the Tibetan areas from the parched, fatigued, polluted Han and Hui Muslim lowlands, is palpable, and produces a spiritual experience for many Han pilgrims upon their arrival. "Shedding tears, sobbing, feeling goose-bumps, kneeling, and kissing the land of Tibet are common emotional manifestations among many first-timer Han pilgrims" (p. 74). These experiences confirm a "hyper-romanticised" image of Tibet among Han Chinese practitioners, comparable to that which prevails in the West. However, what they encounter after they arrive is not always a pure experience of blissful transcendence. Many are unprepared for high-altitude sickness, the harsh climate, and horrific traffic accidents on treacherous roads. The community of fellow disciples is typically riven by jealousies and conflicts, as each vies for preferential access and proximity to the master. Tulkus need talents in internet publishing, translation, fundraising and accounting, and often give higher regard and status to such individuals - or even simply business tycoons who come with huge donations - giving the impression that spiritual attainment is measured and conferred through material contributions. And the Han followers are unprepared to deal with the local Tibetan culture and populations. They require special arrangements, leading them to form ethnic enclaves around monasteries. This can lead to the disembedding of tulkus from their local communities, as they become busy catering to the needs of their wealthy Han patrons, with less time to offer ritual services for local families and communities.

This is but one of the effects of an unprecedented influx of Han devotee money into remote communities. Tempted by generous offerings of cash, growing numbers of tulkus spend most of their time ministering to Han clients in urban centres. The revival of Tibetan Buddhism, for Yü, has led to a "double alienation" as, on the one hand, tulkus become alienated from their local Tibetan communities, while, on the other, their lineages and teachings have become commodities to be sold and consumed for a price. Yü points to the deep irony of the spiritual condition of contemporary China, in which the pervasive materialism and social dislocations caused by neoliberalism have produced a deep spiritual thirst which can find few legitimate outlets in a highly restricted religious field. Under the market economy, however, this desire for spirituality is easily captured by commercial forces, turning the material and symbolic expressions of this yearning into products to be marketed and sold. At the same time, money gives Chinese consumers access to religious knowledge, teachings and networks, helping them to advance their spiritual lives.

The interplay of Buddhism and market occurs within a globalizing context. Westernized Tibetan Buddhism is now penetrating China, finding appeal among Han audiences. Employing a discourse of science and individual self-discovery, proposing technical practices devoid of complex communal ritual, taking place in secular spaces such as university lecture halls or private homes, Westernized Tibetan Buddhism resonates as strongly with secularized, educated Chinese professionals as it does among their counterparts in Europe and North America. At the same time, an image of Tibet as a spiritual paradise is also gaining currency among urban Han, undermining state narratives. Western critics such as Bishop and Lopez have dismissed these images of Shangri-la as an Orientalist "fantasy", a "hallucination" which reveals more about the West itself than about Tibet. These postcolonial critiques have been taken up by proregime Chinese scholars to discredit criticism of China's Tibet policy. But, for Yü, this discourse "is dominated by self-elected modern rationalists who tend to exclude 
imagination from human thinking faculty as if it were the inborn error of humankind, as if ridiculing it, degrading it, and getting rid of it would liberate us from ignorance" ( $p$. 190). What these critics forget, claims Yü, is that imagination is a transformative reality, a spiritual power which Tibetan Buddhism actively cultivates and works with. The imagination of Tibet as a Shangri-la is, then, perfectly legitimate. In fact, the sublime imagination is triggered by the experience of the Tibetan landscape itself. This experience initiates and inspires the sense of the sublime in the pilgrim, whether Chinese or Western. The contrast between these inspirations and the "urban-based, modern mindscape begins to provoke a string of existential, environmental, and spiritual reflections on the ultimate meanings of human life." (p. 191) Far from being a mere chimera, this imagination in contemporary times generates a social, political and ecological resistance to the environmentally and culturally destructive modernization project of the Chinese state in Tibetan regions in particular, and, more generally, to profit-driven exploitative materialism everywhere.

More than a rich ethnographic account which complicates our stereotypes of Tibetan masters, Chinese tourists and Western spiritual seekers, this book offers a treasure-trove of thought-provoking reflections on anthropological theories of charisma, landscape, money, spirituality and globalization. 